\title{
Trends Analysis and Future of Sustainable Palm Oil in Thailand
}

\author{
Ubolrat Wangrakdiskul* \\ Department of Production Engineering, Faculty of Engineering, King Mongkut's University of Technology \\ North Bangkok, Bangkok, Thailand
}

\author{
Nantakrit Yodpijit \\ Department of Industrial Engineering, Faculty of Engineering, King Mongkut's University of Technology North \\ Bangkok, Bangkok, Thailand \\ * Corresponding author. E-mail: ubl@kmutnb.ac.th \\ Received: 4 June 2014; Accepted: 5 January 2015; Published online: 10 February 2015 \\ (C) 2015 King Mongkut's University of Technology North Bangkok. All Rights Reserved.
}

\begin{abstract}
Currently, exhaustion of fossil fuel is one of the serious problems. Oil palm is the prominent oil crop that provides higher yield and consume less energy than the other crops in plantation life. The expansion of oil palm plantation along with the appropriate use of oil palm planted areas and the environmental conservation needs to be concerned. This research aims at analyzing oil palm plantation establishment influencing the sustainable palm oil industry in Thailand. We use an exponential growth model to estimate an increased domestic consumption and production of palm oil for the need of oil palm plantation areas. Therefore, recognition of oil palm plantation with environmental protection by compliance with RSPO standard has also been proposed. For sustainable use, costs structure and productivity improvement of oil palm cultivation is analyzed and suggested.
\end{abstract}

Keywords: Sustainable palm oil, Plantation, Trend analysis

\section{Introduction}

Oil palm is the perennial oil crops which gives the high yield production and can be cultivated in the tropical region such as Indonesia, Malaysia, Thailand, Nigeria, etc. It is originated from West Africa. In 1968, it came to Thailand after the successful of planting in Malaysia [1]. As the prominent of high yield, low cultivation costs, and simply maintenance, these lead to result in expansion of oil palm's cultivation area. Oil palm has the high impact opportunities of producing renewable energy, because its yield is higher than the other oil crops (i.e. soybean and rapeseed oil) as much as 4 times [2].

Due to the rapid increase in crude oil prices during recent decades, it leads an increased use of biodiesel which mostly produced from palm oil. As this result, fresh fruit bunches (FFB) prices per ton have been raised from $\$ 78.88$ USD to $\$ 162.05$ USD or increased by 105\% during 2006-2012 as represented in Table 1. In addition, it also indicates the data of global crude oil prices which have been raised from $\$ 66.25 \mathrm{USD} /$ barrel to $\$ 94.15 \mathrm{USD} /$ barrel or increased by $42 \%$. Both of them have the similar pattern and trend. Notice that, in 2009, FFB prices have also been dropped as the falling of global crude oil prices [3-5].

According to Table 1, the increase of FFB prices has encouraged the farmers to expand their farmland. In 2012, oil palm plantation areas in Thailand are accounted for 680,676 hectares (ha) which increased approximately $160 \%$ in 13 years during 2000-2012 [6]. http://dx.doi.org/10.14416/j.ijast.2015.01.001 
Table 1: Thai fresh fruit bunches (FFB) prices and the global crude oil prices, 2006-2012 [3-5]

\begin{tabular}{|c|c|c|}
\hline Year & $\begin{array}{c}\text { Global Crude Oil Prices } \\
\text { (\$ USD/ barrel) }\end{array}$ & $\begin{array}{c}\text { FFB Prices } \\
\text { (\$ USD/ton) }\end{array}$ \\
\hline 2006 & 66.25 & 78.88 \\
\hline 2007 & 72.41 & 134.32 \\
\hline 2008 & 99.75 & 139.60 \\
\hline 2009 & $62.09^{*}$ & $120.13^{*}$ \\
\hline 2010 & 79.61 & 140.59 \\
\hline 2011 & 95.11 & 176.24 \\
\hline 2012 & 94.15 & 162.05 \\
\hline $\begin{array}{l}\text { \% increased } \\
(2006-2012)\end{array}$ & $42 \%$ & $105 \%$ \\
\hline
\end{tabular}

Since 2005, the local biodiesel has been launched in Thailand. The consumption of biodiesel has gradually increased. Also, there are various oil crops in Thailand, i.e. peanut, soybean, and oil palm. The reports of OAE have been evaluated the revenue of major oil crops production during 2006-2012 [3,7,6]. It can be summarized that oil palm provides the higher revenues than soybean which are between 2.84 to 12.10 times (see Table 2). Similarly, it has the higher revenues than peanut which are between 2.16 to 35.13 times. As these results, they can be concluded that oil palm can generate higher incomes for smallholders.

Table 2: Revenue comparison of oil palm, soybean, and peanut in Thailand, 2006-2012 [3,7,6]

\begin{tabular}{|c|c|c|c|c|c|}
\cline { 2 - 6 } \multicolumn{1}{c|}{} & \multicolumn{2}{c|}{ Revenues (\$ USD/ha) } & \multicolumn{2}{c|}{ Revenue Ratio } \\
\cline { 2 - 6 } \multicolumn{1}{c|}{} & Oil Palm & Soybean & Peanut & $\begin{array}{c}\text { Palm Oil } \\
\text { :Soybean } \\
\text { (times) }\end{array}$ & $\begin{array}{c}\text { Palm Oil } \\
\text { :Peanut } \\
\text { (times) }\end{array}$ \\
\hline 2006 & 501.67 & 62.45 & -18.40 & 8.03 & n/a \\
\hline 2007 & 1105.48 & 255.20 & 31.47 & 4.33 & 35.13 \\
\hline 2008 & 1333.32 & 243.70 & 113.12 & 5.47 & 11.79 \\
\hline 2009 & 489.70 & 127.37 & 219.59 & 3.84 & 2.23 \\
\hline 2010 & 617.91 & 217.38 & 232.18 & 2.84 & 2.66 \\
\hline 2011 & 1517.36 & 125.41 & 409.24 & 12.10 & 3.71 \\
\hline 2012 & 1094.66 & 268.75 & 507.58 & 4.07 & 2.16 \\
\hline
\end{tabular}

In Thailand, oil palm cultivation should be encouraged by the government. Therefore, Alternative Energy Development Plan: AEDP 2012-2021 has been established concerning with the expansion of oil palm planted areas, productivity improvement and increasing oil yield of Fresh Fruit Bunches (FFB) [8]. However, predicting of crude palm oil (CPO) consumption and production in Thailand for preparing the appropriate planted areas have not been proposed. Therefore, the objective of this paper is to predict the future demand and production of palm oil for preparing and exploring the planted areas. Moreover, evaluation the feasibility of oil palm plantation with the economical and environmental aspect is also proposed.

\section{Research Methods}

Fatimah and Ghaffar [9] have proposed the model of forecasting palm oil price in Malaysia. They have analyzed the difference between forecast and actual palm oil price in 1984. The results show that the error of forecast data from actual data is approximately 9.7\%. [9]. In Thailand, it also has the research that forecast oil palm prices. However, it only proposed the model to calculate the palm oil price, the comparison between actual and forecast prices has not been carried out [10]. Many researchers have studied the forecasting models for predicting the future data. The exponential smoothing model is used to examine hourly and daily patterns in hourly data for both utility loads and traffic flows. [11]. Newinpun et al [12] have proposed that exponential smoothing Holt-Winter method is appropriate for estimating peak electric energy demand in the center region of Thailand. Linear Exponential Smoothing was uncovered to become the best model for production planning of metal powder and plastic bearing parts [13]. Exponential growth model has been used for forecasting the population growth $[14,15]$. In addition, decision supporting system of business marketing also used the exponential growth [16].

As mentioned above, exponential model has been used in several researches. In this study, also, has employed exponential growth model for predicting the future data. Forecasting production and consumption palm oil in Thailand is still not performed. For promoting the sustainable palm oil production, the relevant factors should be considered. Therefore, the historical data of palm oil production in the world and Thailand are evaluated. After that, forecasting production and consumption in Thailand has been performed. Then, estimating the required planted areas has been proposed for exploring the available areas with the simplified equation. Although, there is the research studying the Equation of Oil Palm Plantation Areas in Thailand, but it considers the different factors which is complicated [17]. The framework of this study has been illustrated in Figure 1. Its detailed has been described as follows. 


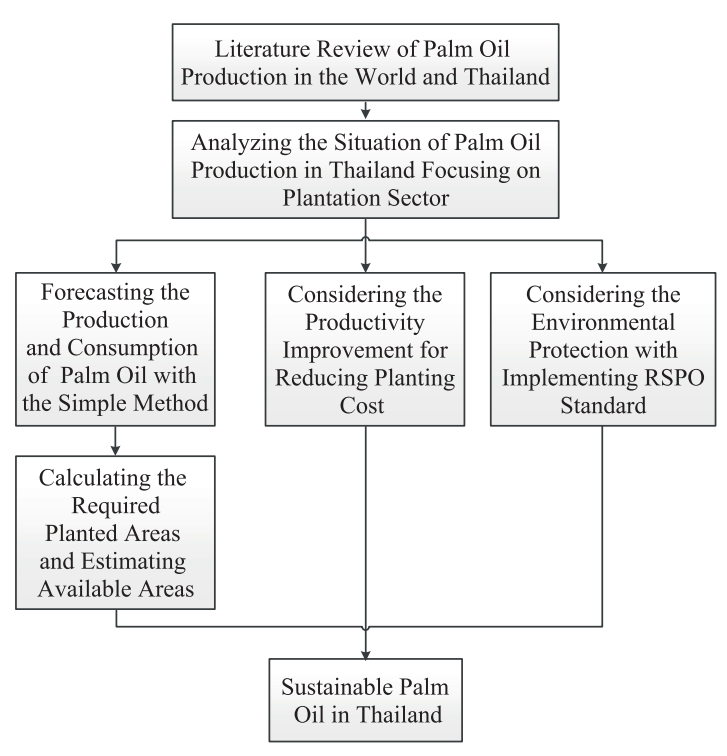

Figure 1: Framework of this study.

\subsection{Forecasting models}

The information of USDA Foreign Agricultural Service in Figure 2 shows the data of palm oil production and domestic consumption in Thailand. It shows the rapid growth of the production and domestic consumption by $29 \%$ and $22 \%$ per year from 1992 to 2012 , respectively [18]. Quantity of palm oil production is higher than domestic consumption, because the excess quantity must be reserved as stocks and export abroad. As the Alternative Energy Development Plan: AEDP 2012-2021, we have forecasted the production and domestic consumption rate of palm oil in the next 5 years by comparing with the ADEP plan. The statistics of production and domestic consumption quantity from 1992-2012 have been used as based data for forecasting. Five steps of this procedure can be explained as follows.

\subsubsection{Analyzing the historical data of palm oil production}

Presently, the world palm oil production has reached $55,308 \times 103$ tones in 2012 increasing 3.26 times from 1992 (see Table 3). Palm oil production of the major producing countries; Indonesia, Malaysia, and Thailand are represented in Table 3 [18]. In 2012, the proportion production of the three major producing countries is $51.5 \%, 34.4 \%$ and $3.6 \%$ of total production,

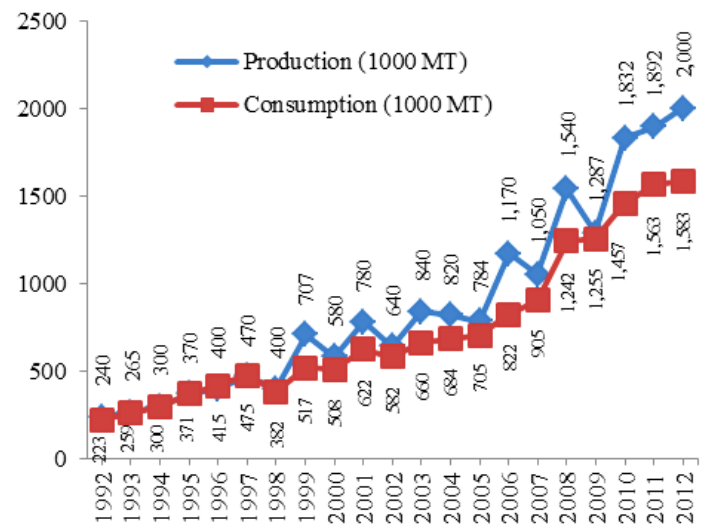

Figure 2: Production and consumption palm oil in Thailand, 1992-2012.

respectively. Production of Indonesia and Malaysia is drastically higher than Thailand, due to the appropriate climate and available areas.

Table 3: Palm oil production of three major producing countries [18]

\begin{tabular}{|c|c|c|c|c|}
\hline \multirow{2}{*}{ Year } & \multicolumn{4}{|c|}{ Palm Oil Production (x1000 tones) } \\
\cline { 2 - 5 } & World & Indonesia & Malaysia & Thailand \\
\hline 1992 & 12,998 & 3,250 & 7,125 & 240 \\
\hline 1993 & 13,726 & 3,900 & 7,100 & 265 \\
\hline 1994 & 14,890 & 4,250 & 7,771 & 300 \\
\hline 1995 & 16,171 & 4,850 & 8,264 & 370 \\
\hline 1996 & 17,626 & 5,385 & 9,005 & 400 \\
\hline 1997 & 16,975 & 5,000 & 8,508 & 470 \\
\hline 1998 & 19,161 & 5,800 & 9,758 & 400 \\
\hline 1999 & 21,677 & 7,200 & 10,491 & 707 \\
\hline 2000 & 24,230 & 8,300 & 11,937 & 580 \\
\hline 2001 & 25,324 & 9,200 & 11,858 & 780 \\
\hline 2002 & 27,654 & 10,300 & 13,180 & 640 \\
\hline 2003 & 29,951 & 11,970 & 13,420 & 840 \\
\hline 2004 & 33,474 & 13,560 & 15,194 & 820 \\
\hline 2005 & 35,749 & 15,560 & 15,485 & 784 \\
\hline 2006 & 37,384 & 16,600 & 15,290 & 1,170 \\
\hline 2007 & 41,138 & 18,000 & 17,567 & 1,050 \\
\hline 2008 & 44,126 & 20,500 & 17,259 & 1,540 \\
\hline 2009 & 45,994 & 22,000 & 17,763 & 1,287 \\
\hline 2010 & 48,752 & 23,600 & 18,211 & 1,832 \\
\hline 2011 & 51,888 & 26,200 & 18,202 & 1,892 \\
\hline 2012 & 55,308 & 28,500 & 19,000 & 2,000 \\
\hline$\%$ Average increased during $1992-2012$ per year & $35 \%$ \\
\hline & & & & \\
\hline
\end{tabular}

According to Table 3, in Thailand, itcan be concluded that there is an increased of palm oil production. 


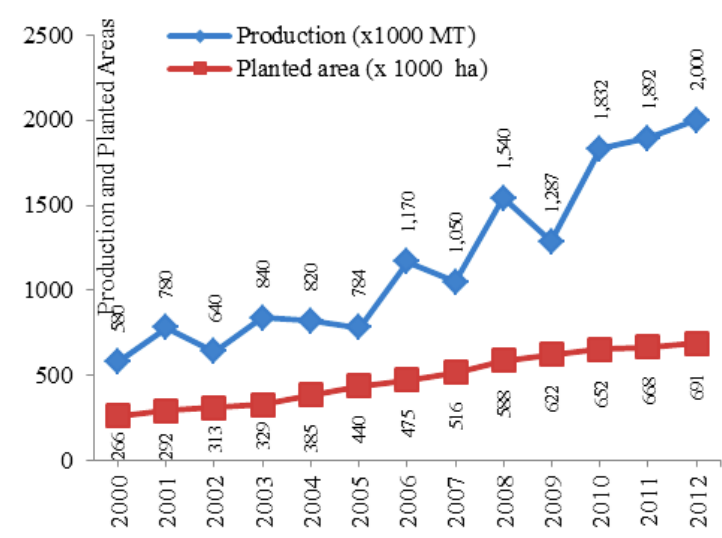

Figure 3: Production and planted areas of palm oil in Thailand, 2000-2012.

Although, the production is falling in 1998, 2000, 2002, 2004-2005, 2007, 2009-2010, these results are caused from the effects of drought climate [19]. However, the average rate of annual palm oil production in Thailand increased approximately $35 \%$ per year during 1992-2012.

\subsubsection{Analyzing the consumption and production of palm oil in Thailand}

Data consumption in Thailand during 1992-2012 have been analyzed and compared with palm oil production. They have been expressed in Figure 2. After 2009, the palm oil production is significantly higher than the consumption by $20.85 \%$ in 2012 . This result comes from the rising of petroleum price since 2009 and leads to the higher consumption and production of palm oil [20]. Notice that, flooding situation in 2011 has an effect on the steady consumption of palm oil during 2011-2012.

Planning for palm oil production along with considering its consumption and planted areas expansion should be concerned. Figure 3 shows the $\mathrm{CPO}$ production which has an increasing trend along with the planted areas expansion. The increased rate of production is higher than that of planted areas which CPO production and planted areas increased by $245 \%$, $160 \%$ during 2000-2012. The planted areas are slowly increased during 2009-2012, due to the remaining areas in Thailand. Therefore, predicting the production and demand of palm oil in the next period for preparing the appropriate planted areas should be performed.

\subsubsection{Selecting the three simple forecasting methods}

The forecasting model which appropriates with the historical data has been selected. Due to the trend of consumption and production crude palm oil, we have used trend analysis of time series forecasting techniques for predicting palm oil production and consumption in Thailand. In this paper, the simple methods are used [21]. They consist of 3 methods which are linear trend, quadratic trend, and exponential growth model.

\subsubsection{Fitting the forecasting models to the data}

Three forecasting models have been used to fit the data pattern which is illustrated as follows.

\section{A. Linear Trend Model}

With historical data trend, the linear trend model has been used to forecast the future consumption demand and production of crude palm oil in Thailand from 2013 to 2021. The equation of this model is expressed in Equation (1).

$Y_{t}=a+b^{*} t$

Where $Y_{t}=$ forecast value at period $t, a=$ the sample Y-axis intercept, $b=$ slope of sample, and $t=$ the period number.

\section{B. Quadratic Trend Model}

In addition to linear trend model, quadratic trend model is one of the simple methods for forecasting trend patterns which can be expressed as Equation (2).

$Y_{t}=a+c_{1}^{*} t+c_{2}^{*} t^{2}$

Where $Y_{t}=$ forecast value at period $t, a=$ the sample Y-axis intercept, $c_{1}$ and $c_{2}=$ coefficient of linear and quadratic, and $t=$ the period number.

\section{Exponential Growth Model}

This is also one of the simple methods for forecasting trend patterns which represented as Equation (3).

$Y_{t}=a^{*} d^{t}$ 
Where $Y_{t}=$ forecasted value at period $t, a=$ the sample Y-axis intercept, $d=$ estimated annual growth rate, and $t=$ the period number.

\subsubsection{Selecting the appropriate model}

As these models, program MINITAB 16.0 has been used to determine the future demand and production palm oil in Thailand and also calculate the required plantation areas of oil palm. The results of these models have been illustrated in section 3 .

\subsection{Relevant factors of palm oil production}

In addition to considering palm oil demand, the other relevant factors for sustainable palm oil production should be concerned. They can be described as follows.

Plantation Cost: In addition to the importance of forecasting palm oil demand and production, the plantation costs are also critical factors. The statistics of plantation cost of oil palm have been shown in Table 4 . By 2012, variable cost is 1439.08 \$ USD/ha which accounts for $83 \%$ of total cost, it leads a high impact on oil palm plantation costs. Therefore, techniques for reducing the variable cost should be investigated [22]

Table 4: The oil palm plantation costs in Thailand, 2002-2012 [6]

\begin{tabular}{|l|c|c|c|c|}
\hline & Variable Cost & Fixed Cost & \multicolumn{2}{|c|}{ Total Cost } \\
\cline { 4 - 5 } & (\$ USD/ha) & (\$ USD/ha) & (\$ USD/ha) & (\$ USD/t) \\
\hline 2002 & 515.85 & 139.96 & 655.81 & 43.17 \\
\hline 2003 & 551.53 & 139.29 & 690.82 & 40.61 \\
\hline 2004 & 535.02 & 139.96 & 674.97 & 40.29 \\
\hline 2005 & 687.34 & 139.96 & 827.29 & 53.73 \\
\hline 2006 & 724.82 & 139.96 & 864.77 & 48.93 \\
\hline 2007 & 740.31 & 139.99 & 880.30 & 58.84 \\
\hline 2008 & 1179.22 & 189.44 & 1368.66 & 68.12 \\
\hline 2009 & 1198.54 & 189.41 & 1387.95 & 86.75 \\
\hline 2010 & 1145.39 & 226.95 & 1372.34 & 94.98 \\
\hline 2011 & 1346.36 & 248.70 & 1595.06 & 88.58 \\
\hline 2012 & 1439.08 & 279.67 & 1718.75 & 96.58 \\
\hline
\end{tabular}

Selling Price: High price of Fresh Fruit Bunches (FFB) makes the oil palm plantation is feasible. Statistics of FFB price and costs of palm oil plantings are indicated in Figure 4. It is clear that the farming is profitable whenever the total cost is less than the selling price. In 2012, the profit of farming is $\$ 60$ USD/ton of FFB. Although, Fresh Fruit Bunches (FFB) price seem to be increased, but trend of profit

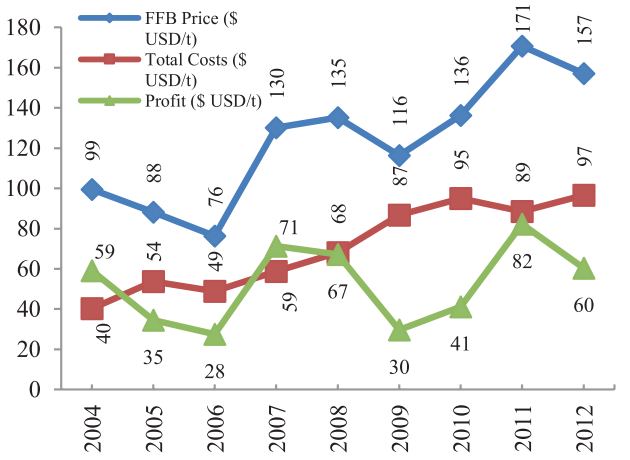

Figure 4: Fresh fruit bunches (FFB) price, total costs and profit of oil palm plantation, 2004-2012 [3,7,6].

is slightly increased. Furthermore, the total cost of oil palm plantation has been increased year by year. In the future, the competition of reducing price may be more serious when AEC is coming in 2015. Therefore, if the selling price of FFB unable to be increased and the total cost are also increased, the farmers may be loss.

Considering these factors, the Malaysia Government has established the agency: theFederal Land Development Authority (FELDA) for gathering the smallholder farmers into the estate of an economic size and providing management and infrastructural inputs to the estate. For overcoming the lack of economies of scale, FELDA's management of smallholders' areas has enabled the resettlement of some 100,000 families who were landless and living below the poverty level. FELDA is today the world's largest single plantation company with a combined oil palm area exceeding 600,000 hectares and an annual revenue exceeding US\$2 billion. With a proven track record, its work is recognized by other developing nations as a model for poverty reduction [23]. For achieving the sustainable plantings of oil palm, Thailand should accommodate the FELDA model to Thai smallholders.

\section{Results}

\subsection{Forecast production and demand of palm oil}

After fitting data with the simple forecasting methods, the results have been described as follows. Based on Equation (1) for forecasting production data, with $a=-46.94, b=83.78$, and $t=1,2, \ldots, 26$ that can be expressed as Equation (4). Similarly, forecasting consumption have been carried out based on Equation (1), 
$\mathrm{a}=16.58, \mathrm{~b}=65.72, \mathrm{t}=1,2, \ldots, n$, and $n=26$ that can be expressed as Equation (5).

Where $Y_{t p}=$ forecast value of palm oil production at period $t$

$Y_{t p}=-46.94+83.78 * t$

$Y_{t c}=16.58+65.72 * t$

Next, Equation (2) of quadratic model is used to calculate forecast data of production and consumption palm oil as expressed in Equation (6) and (7), respectively.

$Y_{t p}=315.84-10.86 * t+4.30 * t^{2}$

Where $a=315.84, c_{1}$ and $c_{2}=-10.86$ and 4.30

$Y_{t c}=322.35-14.04 * t+3.63 * t^{2}$

Where $a=322.35, c_{1}$ and $c_{2}=-14.04$ and 3.63, respectively.

Equation (3) of exponential growth model is also used to calculate forecast data of production and consumption palm oil as expressed in Equation (8) and(9).

$Y_{t p}=230.38 *\left(1.1^{\mathrm{t}}\right)$

Where $a=243.38, d=1.1$

$Y_{t c}=227.19 *\left(1.1^{t}\right)$

Where $a=227.19, d=1.1$

The accuracy measures of forecasting model in this paper have considered the minimum forecasting errors which are MAPE (Mean Absolute Percentage Error), $M A E$ (Mean Absolute Error), and MSE (Mean Square Error) $[21,24,25]$. They are defined in Equation (10), (11), and (12) where $Y_{a}=$ observation data and $Y_{t}=$ forecast data at $\mathrm{t}$ period.

$\% M A P E=\frac{100}{n} \sum_{t=1}^{n} \frac{\left|Y_{a}-Y_{t}\right|}{Y_{a}}$

$M A E=\sum_{t=1}^{n} \frac{\left|Y_{a}-Y_{t}\right|}{n}$

$M S E=\sum_{t=1}^{n} \frac{\left(Y_{a}-Y_{t}\right)^{2}}{n}$
The performance error of forecast data as indicated in Table 5 shows that MAPE, MAE, and MSE of the exponential growth model are lower than the others, especially the $M A P E$ value is approximately $10 \%$.

Table 5: The accuracy measures of 3 forecasting methods for palm oil production and consumption in Thailand, $1992-2013$

\begin{tabular}{|c|c|c|c|c|c|c|}
\hline \multirow{2}{*}{} & \multicolumn{3}{|c|}{$\begin{array}{c}\text { Forecast Production } \\
\text { (x1000 tones) }\end{array}$} & \multicolumn{3}{|c|}{$\begin{array}{c}\text { Forecast Consumption } \\
\text { (x1000 tones) }\end{array}$} \\
\cline { 2 - 7 } & $\mathbf{( 1 )}$ & $\mathbf{( 2 )}$ & $\mathbf{( 3 )}$ & $\mathbf{( 1 )}$ & $\mathbf{( 2 )}$ & $\mathbf{( 3 )}$ \\
\hline \% MAPE & 23.3 & 12.6 & 10.2 & 21.4 & 11.3 & 8.88 \\
\hline MAE & 157.3 & 94.3 & 86.4 & 127.3 & 64.9 & 61.3 \\
\hline MSE & 33773 & 14005 & 12394.5 & 19664 & 5620.9 & 5457.2 \\
\hline
\end{tabular}

Note: $(1)=$ Linear Trend $(2)=$ Quadratic Trend

(3) = Exponential Growth

These results indicate that exponential growth model is the appropriate model for forecasting the future production and consumption palm oil $[26,27]$. The forecast production data of exponential growth model is shown in Table 6. It is projected over the next 5 years (within 2017). The increasing of forecast production is approximately $11.13 \%$ during 2013-2017.

Table 6: Actual production data in 1992- 2012 and forecast production data in 2013-2017 by exponential growth method

\begin{tabular}{|c|c|c|c|}
\hline & \multicolumn{3}{|c|}{ x 1000 tones } \\
\hline Year & $\begin{array}{c}\text { Actual } \\
\text { Production }\end{array}$ & $\begin{array}{c}\text { Forecast } \\
\text { Production }\end{array}$ & $\begin{array}{c}\text { \% Production } \\
\text { Increased }\end{array}$ \\
\hline 1992 & 240 & & \\
\hline 1993 & 265 & & \\
\hline 1994 & 300 & & \\
\hline 1995 & 370 & & \\
\hline 1996 & 400 & & \\
\hline 1997 & 470 & & \\
\hline 1998 & 400 & & \\
\hline 1999 & 707 & & \\
\hline 2000 & 580 & & \\
\hline 2001 & 780 & & \\
\hline 2002 & 640 & & \\
\hline 2003 & 840 & & \\
\hline 2004 & 820 & & \\
\hline 2005 & 784 & & \\
\hline 2006 & 1170 & & \\
\hline 2007 & 1050 & & \\
\hline 2008 & 1540 & & \\
\hline 2009 & 1287 & & \\
\hline 2010 & 1832 & & \\
\hline 2011 & 1892 & & \\
\hline 2012 & 2000 & & \\
\hline 2013 & & 2242 & $12.10 \%$ \\
\hline 2014 & & 2486 & $10.89 \%$ \\
\hline 2015 & & 2757 & $10.89 \%$ \\
\hline 2016 & & 3057 & $10.89 \%$ \\
\hline 2017 & & 3390 & $10.89 \%$ \\
\hline & & & $11.13 \%$ \\
\hline
\end{tabular}


In addition to considering forecast of production, the forecast consumption is also analyzed. Table 7 describes forecast consumption which is approximately increased 9.85\% during 2013-2017.

As the results, the graph of forecast production and demand has been illustrated in Figure 5. In 1992-2012, the average rate of actual production and consumption palm oil increased by $35 \%$ and $29 \%$ per year. The predicted data of production and consumption show that the average rate is increased by $11.13 \%$ and $9.85 \%$ per year in 2013-2017. The data still show the growth rate, although they are not as high as the previous period. As these effects, because there are the restriction of remaining areas for cultivating oil palms.

Table 7: Actual consumption data in 1992-2012 and forecast consumption data in 2013-2017 by exponential growth method

\begin{tabular}{|c|c|c|c|}
\hline \multirow[b]{2}{*}{ Year } & \multicolumn{3}{|c|}{ x 1000 tones } \\
\hline & $\begin{array}{c}\text { Actual } \\
\text { Consumption }\end{array}$ & $\begin{array}{c}\text { Forecast } \\
\text { Consumption }\end{array}$ & $\begin{array}{l}\% \text { Consumption } \\
\text { Increased }\end{array}$ \\
\hline 1992 & 223 & & \\
\hline 1993 & 259 & & \\
\hline 1994 & 300 & & \\
\hline 1995 & 371 & & \\
\hline 1996 & 415 & & \\
\hline 1997 & 475 & & \\
\hline 1998 & 382 & & \\
\hline 1999 & 517 & & \\
\hline 2000 & 508 & & \\
\hline 2001 & 622 & & \\
\hline 2002 & 582 & & \\
\hline 2003 & 660 & & \\
\hline 2004 & 684 & & \\
\hline 2005 & 705 & & \\
\hline 2006 & 822 & & \\
\hline 2007 & 905 & & \\
\hline 2008 & 1242 & & \\
\hline 2009 & 1255 & & \\
\hline 2010 & 1457 & & \\
\hline 2011 & 1563 & & \\
\hline 2012 & 1583 & & \\
\hline 2013 & & 1747 & $10.38 \%$ \\
\hline 2014 & & 1917 & $9.72 \%$ \\
\hline 2015 & & 2103 & $9.72 \%$ \\
\hline 2016 & & 2308 & $9.72 \%$ \\
\hline 2017 & & 2532 & $9.72 \%$ \\
\hline & Average & $9.85 \%$ & \\
\hline
\end{tabular}

Comparing the quantity of forecast production and consumption data, the forecast production data are higher than forecast consumption data (see Table 8). The average value is $23.69 \%$ which can be reserved as yearly ending stock. The higher quantity can be produced diesel fuels containing greater than $5 \%$ biodiesel (B5). Furthermore, some of palm oil remaining can be export aboard.
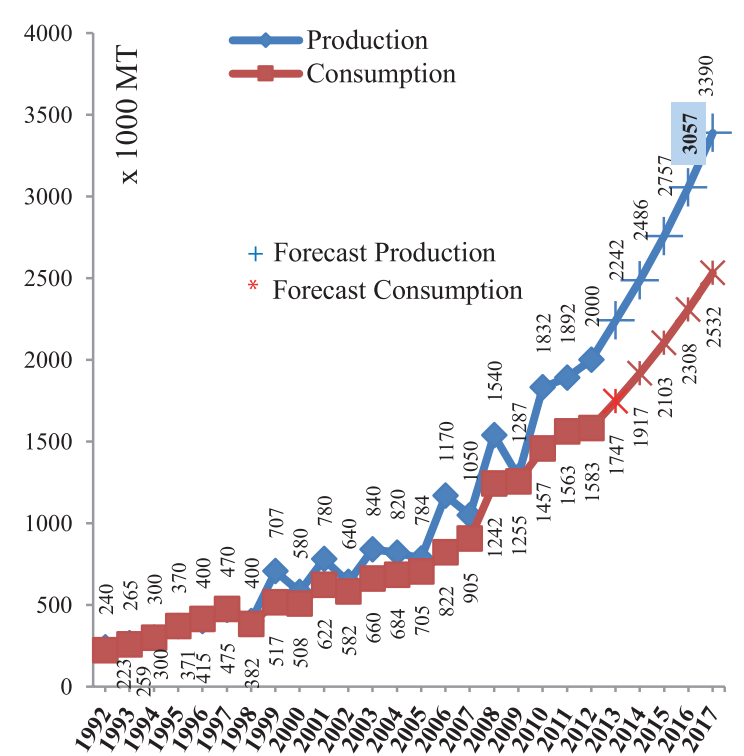

Figure 5: Actual and forecast data of production and consumption Crude Palm Oil (CPO) in Thailand by exponential growth model.

When considering ADEP 2012-2021 plan [8], the target production of palm oil is $3.05 \times 10^{6}$ tones per year within 2021. However, the forecast production palm oil as indicated in Figure 5 can achieve this target since 2016.

Table 8: Comparison the difference between the forecast production and demand data

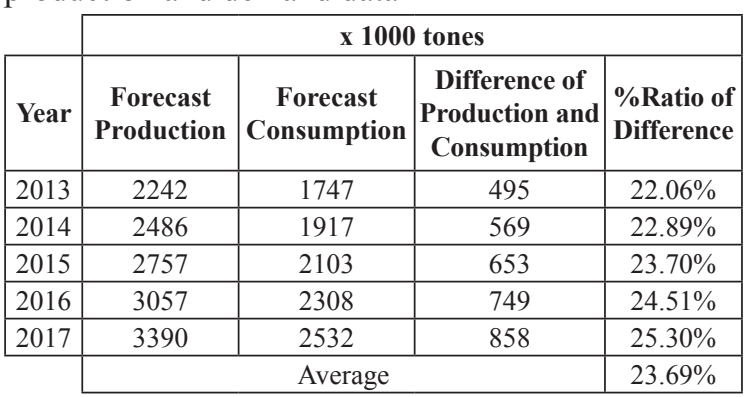

\subsection{Determination of required oil palm planted areas}

Planted areas should be recognized, because they relate with the production planning of palm oil. From the forecast production, we can estimate the required 
areas for planting oil palms as illustrated in Table 9. We use the average yield of cultivation from $\mathrm{OAE}[3,4,6]$ which is 16.94 tones/ha. Oil Extraction Rate (OER) is accounted for $17 \%$ which is based on the report of Appalasamy [28]. The mature planted areas calculated by using forecast CPO production which divided by average yield of plantings and \%OER of palm oil. The required areas are approximately $1.18 \times 10^{6}$ ha. Supporting this requirement, the areas for cultivating oil palm plant should be investigated. The report of National Statistical Office has indicated that the overall waste lands and miscellaneous lands in Thailand are $1.34 \times 10^{6}$ ha in 2011 [29]. The current areas of oil palm plantation are $0.69 \times 10^{6}$ ha (see Figure 3 ). Therefore, the additional areas required for cultivating oil palm plants are approximately $(1.18-0.69) \times 10^{6}=0.49 \times 10^{6}$ ha during 2012-2017. However, the remaining areas are higher than the required areas. It can be concluded that there are sufficient lands for reservation of cultivating oil palms. Furthermore, the ADEP 20122021 target also has been achieved before 2021 .

Table 9: Estimation the required areas of plantation as the forecast production of Crude Palm Oil (CPO) in 2017

\begin{tabular}{|c|c|c|c|}
\hline $\begin{array}{c}\text { Forecast CPO } \\
\text { Production } \\
\text { (x1000 MT/ } \\
\text { year) }\end{array}$ & $\begin{array}{c}\text { Average Yield } \\
\text { (tones/ha) }\end{array}$ & $\begin{array}{c}\text { \%OER } \\
\text { (Oil Extraction } \\
\text { Rate) }\end{array}$ & $\begin{array}{c}\text { Required } \\
\text { Planted Areas } \\
\mathbf{( 1 0}^{6} \text { ha) }\end{array}$ \\
\hline $3,389.6^{(1)}$ & $16.94^{(2)}$ & $17^{(3)}$ & $1.18^{(4)}$ \\
\hline
\end{tabular}

(1) = Forecast data from Figure 4. (3) $=$ From [28]

(2) $=$ From OAE $[3,4,6] \quad$ (4) $={ }^{(1)} \div{ }^{(2)} \div$ (3)

\subsection{Improving the productivity of oil palm plantation}

According to Figure 3, FFB prices are higher than total costs of plantings. It makes oil palm farming profitable in 2004-2012. However, in 2013, the situation of FFB prices is serious. The prices are falling down to $\$ 114.2$ $\mathrm{USD} /$ ton [30]. If the total costs are still \$ $97 \mathrm{USD} /$ ton, the profit of oil palm plantation may fall down from $\$ 60 \mathrm{USD} /$ ton to $\$ 17.2 \mathrm{USD} /$ ton.

According to Table 4, the total cost in 2012 has been used to classify the cost structure of oil palm plantation. It is illustrated in Table 10 which indicates that the main cost is fertilizer cost. It is approximately $\$ 51.4 \mathrm{USD} /$ ton. For reducing this cost, these alternative methods have been proposed.
Table 10: Cost structure of oil palm plantation

\begin{tabular}{|l|c|c|}
\hline \multicolumn{1}{|c|}{ Cost } & $\mathbf{\%}^{{ }^{(1)}}$ & \$ USD/ ton \\
\hline Fertilizer Cost & 53.22 & 51.40 \\
\hline Applying Fertilizer Cost & 1.33 & 1.28 \\
\hline Pruning Oil Palm Frond Cost & 5.17 & 4.99 \\
\hline Weed Control Cost & 4.8 & 4.64 \\
\hline Harvesting Cost & 19.96 & 19.28 \\
\hline Material Handling Cost & 13.3 & 12.85 \\
\hline Miscellaneous Cost & 2.22 & 2.14 \\
\hline Total Cost & & 96.58 \\
\hline
\end{tabular}

(1) From [31]

\subsubsection{Using natural fertilizer.}

In this study, planting oil palm should employ oil palm frond, Empty Fruit Bunches (EFB) of oil palm instead of chemical fertilizer. As this method, it can cut down the cost $30 \%$ which is approximately \$ $15.42 \mathrm{USD} /$ ton.

\subsubsection{Implementing Good Agricultural Practice (GAP)}

Improving the plantation method for reducing variable cost, such as fertilizing management, implementing GAP (Good Agricultural Practice) is should be considered. It can improve productivity and reduce cost of planting. Some methods of GAP have been proposed as shown in Table 11 [32].

\subsection{Environmental concern with RSPO standard}

Considering the environmental protection, the expansion of oil palm planted areas has posed an environment threat. These impacts come from expanding oil palm's cultivation areas by the leading countries, Malaysia and Indonesia. They have changed their forests to cultivate oil palm plant instead. These lead the effect on deforestation, tropical biodiversity, and climate change of the environment [33,34]. Many researchers have expressed and suggested the farmers who cultivate oil palm to comply with RSPO (Roundtable on Sustainable Palm Oil) for alleviating these problems $[35,36]$.

RSPO standard has been established since 2004 to promote the growth and use of sustainable oil palm products through credible global standards and engagement of stakeholders. It is a non-profit organization that unites stakeholders from seven sectors of the palm oil industry, oil palm farmers, palm oil processors or traders, consumer goods manufacturers, retailers, banks and investors, environmental or nature 
conservation (NGOs) and social or developmental (NGOs) to develop and implement global standards for sustainable palm oil [37]. Protecting biodiversity, preventing deforestation and greenhouse gas emission are the main focus of the RSPO standard. Non certified RSPO products could not export to EU in the future. As this, the farmers in Thailand who planting this oil crop should comply with RSPO standard. However, there are limitations of implementation this standard toward oil palm farmers. Most of them are smallholder farmers who have the limitations on lacking of budget, low education level, and negative farming attitude. Therefore, the Thai government should support the farmers i.e. providing budget for implementing RSPO, training the farmers by expert trainers for enhancing farmers' performance [38]. Implementing RSPO of palm oil plantation can help the farmers to enhance their productivity and increase oil yield or \%OER. These results can increase the wealth in farmers and make the sustainable palm oil in Thailand as well.

Table 11: Concepts of implementing GAP in oil palm planting. [32]

\begin{tabular}{|l|l|}
\hline \multicolumn{1}{|c|}{ Items } & \multicolumn{1}{c|}{ Methods } \\
\hline Soil Fertility & $\begin{array}{l}\text { 1. Organic matter is important for maintaining } \\
\text { soil health and soil structure, as well as reducing } \\
\text { soil loss and increasing nutrient and water use } \\
\text { efficiency. Organic matter levels should be } \\
\text { maintained at, or improved to a satisfactory } \\
\text { equilibrium value for the soil type. } \\
\text { 2. Organic matter levels can be improved by adding } \\
\text { waste biomass from palm oil processing, such as } \\
\text { empty fruit bunches, mill effluent and decanter } \\
\text { solids, palm shell and fibre. }\end{array}$ \\
\hline Nutrients & $\begin{array}{l}\text { 1. Economic sustainability requires the use of } \\
\text { fertilisers on most soils. Ideally, total nutrient inputs } \\
\text { (including those from soil mineralisation and } \\
\text { compostimported) shouldbe very similartonutrients } \\
\text { exported in the harvested product plus that stored } \\
\text { in vegetation and the soil and palm biomass. } \\
\text { 2. Loss ofnutrients-inwastes, through volatilisation, } \\
\text { to surface and ground water and through sediment } \\
\text { erosion - must be minimised. The proportion of } \\
\text { nitrogen (N) input from biological fixation should } \\
\text { bemaximised. Appropriate micronutrient additions } \\
\text { will enhance the efficiency of use of nitrogen (N), } \\
\text { phosphorus (P) and potassium (K) as well as } \\
\text { meeting the crop's micro-nutrient needs. }\end{array}$ \\
\hline Pest & $\begin{array}{l}\text { 1. Integrated Pest Management (IPM) is the key } \\
\text { to sustainable pest control. The objective is to } \\
\text { adopt cultural, biological, mechanical, physical } \\
\text { or other less-hazardous strategies to minimise the } \\
\text { use of pesticides. } \\
\text { 2. IPM is therefore the careful consideration } \\
\text { of all these available pest control techniques } \\
\text { and their subsequent integrated use to improve } \\
\text { biological balance. } \\
\text { 3. This should discourage the development of pest } \\
\text { populations . For rats, establish and maintain owl } \\
\text { nest boxes and monitor occupancy. If socially } \\
\text { acceptable locally, snakes and large reptiles may } \\
\text { also be encouraged. }\end{array}$ \\
\hline
\end{tabular}

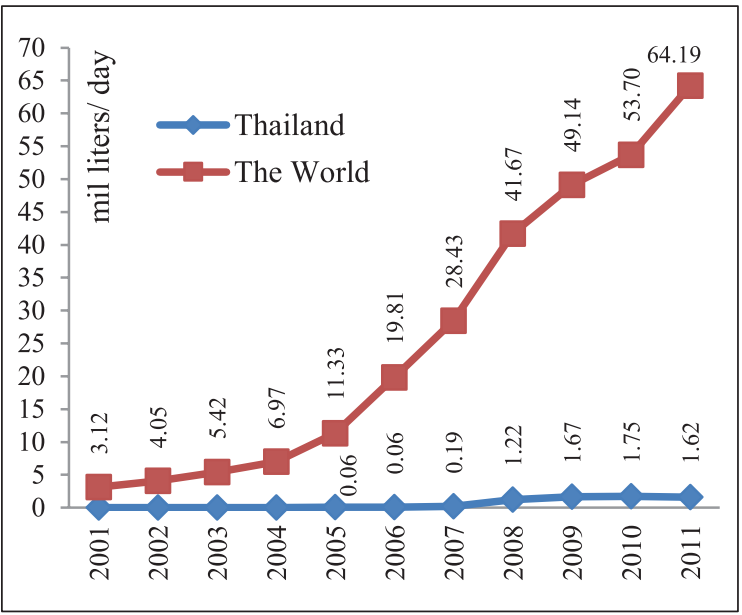

Figure 6: Biodiesel production in the world and Thailand, 2001-2011[40].

In the following section, conclusions and discussions the results will be summarized. Moreover, suggestions of future sustainable palm oil also have been proposed i.e. the arrangement of cultivation oil palm plants, for successfully implementing the ADEP 2012-2021 plan.

\section{Conclusions and Discussions}

In the previous section, the results show that the exponential growth model is the appropriate method for forecasting production and consumption palm oil in Thailand with the minimum errors of MAPE, MAE, and MSE. Considering Table 8, the forecast production is higher than the forecast consumption by $23.69 \%$. The remaining of palm oil is reserved as ending stock and export aboard. In addition, The Thai Government's biodiesel policy aims to promote biofuel production for reducing its dependency on oil imports and to capitalize on its supplies of feedstock from its agricultural production [39]. Biodiesel production in Thailand has been started in 2003 as depicted in Figure 6 [40]. It is gradually increased until 2011. The production of biodiesel is only accounted for $1.62 \mathrm{mil}$ litres/day. When comparing with production of biodiesel in the world, Thailand's production is just only $3 \%$. Therefore, the palm oil production, which is higher than the consumption, can be promoted to produce biodiesel with increasing the composition of palm oil in the biodiesel formula. 
However, the exponential growth model just has some advantages and disadvantages which indicated in Table 12. As its disadvantages, the other model for forecasting future data should be employed in the future work such as regression model.

Table 12: Advantages and disadvantages of the exponential growth model

\begin{tabular}{|l|l|}
\hline \multicolumn{1}{|c|}{ Advantage } & \multicolumn{1}{c|}{ Disadvantage } \\
\hline $\begin{array}{l}\text { 1. Exponential growth models } \\
\text { can be used to describe a data } \\
\text { in its beginning stages, before } \\
\text { planting areas limitations } \\
\text { become significant. }\end{array}$ & $\begin{array}{l}\text { 1. When the planting areas } \\
\text { starts restricting production } \\
\text { growth, the exponential growth } \\
\text { model may be inappropriate. }\end{array}$ \\
\hline $\begin{array}{l}\text { 2. The exponential growth } \\
\text { model is easy to be used for } \\
\text { predicting the future. }\end{array}$ & $\begin{array}{l}\text { 2. Some factors affecting } \\
\text { the future data have not been } \\
\text { calculated in the model, i.e. crude } \\
\text { oil price, fresh fruit bunches } \\
\text { price, planting areas etc. }\end{array}$ \\
\hline
\end{tabular}

The Thai government has encouraged the fuel producers to blend palm oil with diesel fuel and recently announced new mandates that will increase blending requirements to B7 (7 percent blend by volume of biodiesel in diesel fuel) in 2014 [41]. Currently, the formula of biodiesel in Thailand is just only B5 [42]. The program of using more palm oil for substitution in biodiesel should be sped up. Promoting sustainable of production palm oil in Thailand is the challenge task for the related sectors to make it successful.

In summary, implementing of RSPO and providing budget through smallholder farmers should be supported by the government. In addition, increasing yield (i.e. implementing RSPO standard, GAP, BMP management) and reducing variable cost of plantings oil palm (i.e. labour cost) are the important factors for the sustainable palm oil production in Thailand.

\section{References}

[1] D. Sheil,A. Casson, E. Meijaard, van M.Noordwijk, J. Gaskell, J. Sunderland-Groves, K. Wertz, and M. Kanninen, The Impacts and Opportunities of Oil Palm in Southeast Asia, What do We Know and What do We Need to Know?, Published by Center for International Forestry Research, 2009, pp.1-11.

[2] S. Mekhilef, S. Siga, and R.Saidur, "A review on palm oil biodiesel as a source of renewable fuel,"
Renewable and Sustainable Energy Reviews, vol. 15, pp. 1937-1949, 2011.

[3] OAE (Office of Agricultural Economics), "Fundamental Information of Agricultural Economics 2008," Ministry of Agriculture and Cooperative, Bangkok, Thailand, 2008.

[4] OAE (Office of Agricultural Economics), "Fundamental Information of Agricultural Economics 2011," Ministry of Agriculture and Cooperative, Bangkok, Thailand, 2011.

[5] EIA, U.S. Energy Information Administration, (2012a.). Independent Statistics and Analysis. U.S. Department of Energy. [Online]. Available: http://www.eia.gov/dnav/pet/hist/LeafHandler. $\operatorname{ash} \mathrm{x} ? \mathrm{n}=$ pet $\& \mathrm{~s}=\mathrm{rclc} 1 \& \mathrm{f}=\mathrm{a}$

[6] OAE (Office of Agricultural Economics), "Fundamental Information of Agricultural Economics 2012," Ministry of Agriculture and Cooperative, Bangkok, Thailand, 2012.

[7] OAE (Office of Agricultural Economics), "Fundamental Information of Agricultural Economics 2009," Ministry of Agriculture and Cooperative, Bangkok, Thailand, 2009.

[8] DEDE (Department of Alternative Energy Development and Efficiency). "Alternative Energy Development Plan: AEDP 2012-2021," Ministry of Energy, 2012a.

[9] M.A. Fatimah and R.A. Ghaffar, "Crude Palm Oil Price Forecasting: Box-Jenkins Approach," Pertanika, vol. 9(3), pp. 359-67, 1986.

[10] R. Nochai and T. Nochai, "ARIMA Model for Forecasting Oil Palm Price: 2nd IMT-GT Regional Conference on Mathematics," Statistic and Applications, University Sains Malaysia, Penang, June 13-15, 2006.

[11] P.G. Gould, A.B. Koehler, F. Vahid-Araghi, R.D. Snyder, J.K. Ord, and R.J. Hyndman, "Forecasting time-series with multiple seasonal patterns," European Journal of Operational Research., vol. 191, pp. 207-222, 2008.

[12] J. Newinpun, B. Chomtee, and P. Payakkapong, "A Comparison of the Four Forecasting Methods for Peak Electric Energy Demand in the Center Region of Thailand," in Graduate Research Conference 2012, Khon kaen University, 2012.

[13] J. Supanakorn, "Time Series Forecasting for Production Planning of Bearing Parts, " The Journal of KMUTNB., vol. 21(3), pp. 595-606, 
Sep.-Dec. 2011.

[14] M. Ebersbach, M. Lehner, C. M. Resing, and F. Wilkening, "Forecasting exponential growth and exponential decline: Similarities and differences," Acta Psychologica, vol. 127, pp. 247257, 2008.

[15] M. Ebersbach, W.Van Dooren, W. Van den Noortgate, and W. C. M. Resing, "Understanding linear and exponential growth: Searching for the roots in 6- to 9-yearolds" Cognitive Development, vol. 23, pp. 237-257, 2008.

[16] D. Arnott, and P. O'Donnell, "A note on an experimental study of DSS and forecasting exponential growth," Decision Support Systems, vol. 45(1), pp.180-186, 2008.

[17] P. Phitthayaphinant1, A.Nissapa1, B. Somboonsuke1, and T. Eksomtramage, "An Equation of Oil Palm Plantation Areas in Thailand," KKU Research Journal, vol. 11(1), pp. 66-76, 2011.

[18] Foreign Agricultural Service. (2012). Production, Supply and Distribution Online. United States Department of Agriculture. [Online]. Available: http://www.fas.usda.gov/psdonline/psdQuery. aspx

[19] Univanich Annual Report, (2012). Univanich Public Palm Oil Company. [Online]. Available: www.univanich.com/AnnualReport/2012/ ar2012en.pdf

[20] EIA (U.S. Energy Information Administration), (2012b). International Energy Statistics. U.S. Department of Energy. [Online]. Available: http:// www.eia.gov/cfapps/ipdbproject/iedindex3.cfm? tid $=79 \&$ pid $=81 \&$ aid $=1 \&$ cid=regions, $\&$ syid $=200$ $1 \&$ eyid=2011\&unit=TBPD

[21] Z. Li, J. M. Rose, and D.A. Hensher, "Forecasting Automobile Petrol Demand in Australia: An Evaluation of Empirical Models," Transportation Research Part A, vol. 44, pp. 16-38, 2010.

[22] T. Rhebergen, "Analysis of Implementation of Best Management Practices in Oil Palm Plantations in Indonesia," Thesis, Wageningen University, 2012.

[23] Y. Basiron, "Palm oil production through sustainable plantations," European Journal of Lipid Science and Technology, vol. 109, pp. 289-295, 2007.

[24] P. Zhou, B.W. Ang, and K.L. Poh, “A trigonometric grey prediction approach to forecasting electricity demand," Energy, 2006, vol. 31(14), pp. 2839-2847.

[25] H.T. Pao, "Forecasting energy consumption in Taiwan using hybrid nonlinear models," Energy, vol. 34, pp. 1438-1446, 2009.

[26] W. C. Dunn, “A More Comprehensive Life Cycle Cost Analysis of Pavement Materials Alternatives," Thesis, Massachusetts Institution of Technology, 2013.

[27] S.K. Smith, and M. Shahidullah, "An evaluation of population projection errors for census tracts," Journal of the American Statistical Association, vol. 90(429), pp. 64-71, 1995.

[28] S. Appalasamy. (2012). Community Enterprise Group for Sustainable Palm Oil Production (Chonburi). [Online]. Available: http://www. rspo.org/sites/default/files/The_Sustainable_Oil Palm_Smallholders_Production_Community_ Enterprise_Group_Chonburi_Summary_Report_ v3_1-86.pdf

[29] NSO (National Statistical Office), (2012). Statistics of Land, Whole Kingdom: 2002-2011. [Online]. Available: service.nso.go.th/nso/nsopublish/ BaseStat/tables/.../100101_45-54.xls

[30] DIT (Department of International Trade), (2013 Sep. 6). Surathani Province, Ministry of Commerce, Thailand, [Online]. Available: http://www.dit. go.th/SuratThani/index.asp?deptid $=66$

[31] Provincial Agricultural Extension Office: Suratthani. Department of Agricultural Extension. (2013). [Online]. Available: http://suratthani. doae.go.th

[32] Sustainable Palm Oil, (2013). Good Agricultural Practice Guidelines. Part of the Unilever Sustainable Agriculture Initiative. [Online]. Available: http:// www.growingforthefuture.com

[33] L.P. Koh and D.S. Wilcove, "Is oil palm agriculture really destroying tropical biodiversity?," Conservation Letter, vol. 1, pp. 60-64, 2008.

[34] K.T. Tan, K.T. Lee, A.R. Mohamed, and S. Bhatia, "Palm oil: addressing issues and towards sustainable development," Renewable Sustainable Energy Reviews, vol. 13(2), pp. 420-427, 2009.

[35] M.K. Lam, K.T.Tan, K. Lee, and A.R. Mohamed, "Malaysian palm oil: surviving the food versus fuel dispute for a sustainable future," Renewable and Sustainable Energy Reviews, vol. 13(6-7), pp. 1456-64, 2009.

[36] J.S.H. Lee, L. Rist, K.Obidzinski, J. Ghazoul, and 
L.P. Koh, "No farmer left behind in sustainable biofuel production", Biological Conservation, vol. 144, pp. 2512-2516, 2011.

[37] RSPO (Roundtable on Sustainable Palm Oil), (2012). An International Multi Stakeholder Organization and Certification Scheme for Sustainable Palm Oil. [Online]. Available: http:// www.rspo.org/en/history.

[38] U. Wangrakdiskul and N. Yodpijit, "Roundtable on Sustainable Palm Oil (RSPO) in Smallholder Farmers of Thailand," in The 13th Asia Pacific Industrial Engineering and Management Systems Conference (APIEMS 2012), Phuket, Thailand, Dec. 2-5, 2012.

[39] S. Kumar, P. Shrestha, and P. AbdulSalam, “A review of biofuel policies in the major biofuel producing countries of ASEAN: Production, targets, policy drivers and impacts," Renewable and Sustainable Energy Reviews, vol. 26, pp.822-836, 2013.

[40] EIA (U.S. Energy Information Administration), (2012a). Independent Statistics and Analysis. U.S. Department of Energy, [Online]. Available: http://www.eia.gov/dnav/pet/hist/LeafHandler. $\operatorname{ash} \mathrm{x} ? \mathrm{n}=$ pet $\& \mathrm{~s}=\mathrm{rclc} 1 \& \mathrm{f}=\mathrm{a}$

[41] GAIN (Global Agricultural Information Network), "Thailand Biofuels Annual 2013," USDA, 2013.

[42] J. Wilkinson, S. Afiff, M. Carriquiry, C. Jumbe, and T. Searchinger, (2013). Biofuels and Food Security. [Online]. Available: http://typo3. fao.org/fileadmin/user_upload/ hlpe/hlpe documents/_Biofuels/HLPE_V0_draft report Biofuels_and_Food_Security-09-Jan-2013.pdf 